\title{
AR-Sis: AugMENTED REALITY APPLICATION TO ENCOURAGE STEM TEACHING AND LEARNING
}

\author{
Nadia Akma Ahmad Zaki, Nor Zuhaidah Mohamed Zain and \\ Asmafitri Zanilabdin \\ Computing Department, Faculty of Art, Computing and Creative Industry, \\ Universiti Pendidikan Sultan Idris, Tanjong Malim, Perak, Malaysia
}

\begin{abstract}
Augmented reality in STEM education has been identified to be useful to students as indicated in many studies. However, the interest of the students towards STEM education is reportedly declining. Thus, this study supports the concept of STEM education through the development of an AR application namely ARSiS that aims to encourage students to study Science subjects. The objective of this study is to develop and evaluate the usability AR-SiS application in teaching the solar system sub-topic. The respondents of this study consist of two categories, namely five teachers and twenty students (Year 4 to 6). The result found that both categories of respondents showed a high mean score on learnability and satisfaction toward the use of AR-SiS application. Hence, it is hoped that this study will benefit the students who are interested in STEM education and contribute the teachers a chance to diversify the teaching aids in the classroom.
\end{abstract}

\section{KEYWORDS}

Augmented Reality, Encourage, Teaching, Learning, STEM

\section{INTRODUCTION}

Technology-based research to improve learning (technology-enhanced learning) such as augmented reality, ubiquitous learning (u-learning), mobile learning (m-learning), serious games and learning analytics have been widely used to provide user satisfaction and experience in enriching the environment multimodal learning [1]. Among these technologies, the use of augmented reality (AR) is seen increasingly popular to enhance learning and teaching experiences in the classroom by encouraging students to explore learning materials from a new perspective [2]-[3]. Besides, the use of AR technologies in practical applications such as high potential education to improve the existing technology towards better quality of life [4].

Science, technology, engineering and mathematics (STEM) education have been recognized as a main learning in education at schools around the world [5]. In line with the 4th Industrial Revolution, various STEM initiatives at all levels of education in Malaysia were implemented to achieve the goal of producing sufficient STEM workforce and the new millennium community that are well-versed in STEM [6]. However, only 23\% of senior high school students were enrolled in Pure Science stream in Malaysia and the decline in the interest in STEM education is seen to be more serious [7], which also causes the deterioration of students taking the Science stream at higher education institutions. Among the factors are due to lack of interest and the 
The International Journal of Multimedia \& Its Applications (IJMA) Vol.10, No.6, December 2018

perception of the difficult level of studying in the field. Students, who are numerically challenged, view that mathematics and science will hinder their progress in mastering in both the fields, accordingly. Besides, many students perceive teaching or pedagogy in the STEM field as less interesting and assume that this field is less likely to offer job opportunities [8].

Based on studies pertaining the use of AR technology especially in STEM education [9]-[11], a combination of efforts to improve and enhance STEM education through the use of AR in the Malaysian education context is the main focus of the study. The selection of the Solar System topic, which is one of the topics in Science Year 4, was conducted as many students faced difficulty in understanding the complex knowledge of concepts, phenomena and space-related theories [12]. The difficulty in understanding astronomical concepts occurs as the students' needs to explore the concept of a three-dimensional (3D) object relationships in space and the students' view of the different perspectives are limited. This is due to the many astronomical sources that are available in the form of two-dimensional (2D) charts and images as in school textbooks. The findings [12] found that the use of 3D technology is one of the approaches to support students in building and describing scientific phenomena effectively.

According to [13], AR technology allows user interaction with virtual objects in the form of 2D or 3D combined into a real environment. Hence, the use of AR technology is appropriate for STEM education by highlighting the teaching approach based inquiry. Through this approach, students' inquiry skills can be nurtured through their direct involvement or interaction with learning materials in challenging assignments [14]. In addition, teachers can diversify the teaching techniques and aids used during learning and facilitating sessions by incorporating AR technology. Therefore, the focus of this study is to develop and evaluate the usability of an application on the solar system topic using AR technology. An application known as AR-SiS is expected to attract students' interest in Science subjects, as well as to encourage STEM learning and teaching, which will be used by teachers as a teaching techniques and aids in the classroom.

\section{Related STUdy}

\subsection{Augmented ReAlity (AR)}

AR technology is one of the technologies that create an environment where information is generated by computers with real world scenes. Nonetheless, the AR definition is argued to vary based on studies [1]. For example, according to [13], AR allows interactions with virtual objects in the form of 2D or 3D that are united in a real environment. However, [15] states AR refers to the technology that displays digital material into real-world objects. This definition is based on one of the AR features of putting something on something else or superimposes virtual information into real world objects. In addition, a broader perspective is used in the study, whereby [16] indicates AR as a continuation or extension to virtual reality (VR), but with some advantages. AR research is also evolving and now available on mobile and non-mobile devices.

\subsection{AUGMENTED REALITY (AR) IN STEM EDUCATION}

A study on the AR technology trends in education has shown an improvement especially in improving learning, motivation, interaction and collaboration [1], [4]. According to research [17], among others, AR technology provides an avenue to students in improving learning 
The International Journal of Multimedia \& Its Applications (IJMA) Vol.10, No.6, December 2018 performance, being active in engagement, and have a positive attitude. In addition, AR technology has also proven to be effective in increasing involvement in learning and understanding of a particular topic, especially when it involves spatial visualization skills [2]. In addition, there are some examples of using AR technology in education such as in study [18] about terrain shape learning, electrochemical concept [19], civil engineering education [20], second language learning [21], and human anatomy learning which is digestive system [22]. The use of AR technology is believed to improve the experience in teaching and learning, as well as through the interactive dimensions provided to strengthen the remembering process [23].

Study by[9] found that the use of AR technology in STEM education has been increasing and suggested further research should focus on science skill-based outcomes. Among the advantages of using AR technology in STEM education is to provide students with the opportunity to develop practical skills through learning experiences, encouraging involvement, motivation and satisfaction of students [11], [24]. Based on these advantages, it is clear that students and teachers should utilize the use of AR in education, especially in STEM education.

\subsection{STEM EDUCATION}

The STEM education concept is an effort to attract youth in learning science, technology, engineering and mathematics. STEM education is a learning that moves beyond facts and procedures by introducing broad concepts, such as scales or systems, and involving students in STEM practices such as developing evidence-based explanations [25]. This growing perspective requires active learning mode and activities that emphasize practicality and reality. According to [26], various studies have proved that STEM education is effective in raising students' interest in Science and Mathematics, and success in STEM-related occupations. He added that the current trend is to combine the four STEM disciplines into a mega-discipline considered practical and realistic to foster students' interest in Science and Mathematics at schools. STEM education also provides an opportunity for students to apply the Science and Mathematical concepts and make learning more meaningful and challenging.

STEM education is now a priority in the Malaysian education, in line with the government's desire to improve the percentage of student's interest in STEM education either at school or in higher education. As a preliminary step, students need to be exposed to STEM education as early as possible in primary school by applying the technologies that have been rapidly growing. According to [27], studies about STEM education also represent high empirical efforts to create a better understanding of the basic factors that influence the success of the student throughout the STEM learning process. Therefore, it is hoped that this study will contribute to the generation of STEM-based students who are able to compete in professional, scientific and technical fields.

\section{ReSEARCH Methodology}

Various methodology theories can be applied throughout the product development process that apply AR and VR technologies such as the ADDIE model (Analysis, Design, Development, Implementation, and Evaluation), VRID model (Virtual Reality Interface Design) or R2D2 (Recursive and Reflective Design and Development) [28]. For AR-SiS application development, the ADDIE model containing five phases which are analysis, design, product development, implementation and evaluation phases have been selected as suitable for product development 
The International Journal of Multimedia \& Its Applications (IJMA) Vol.10, No.6, December 2018 that applies AR technology and instructional design [28]. Beginning with the analysis phase, the researcher analysed the needs of the study on existing markets and made comparisons on some of the elements that are possible and should be applied in the production of researched products as well as improving the products to be produced. Next, in the design phase, the technical, material and media specification requirements are set. Flow charts and storyboards are created to facilitate researcher to refer to the preliminary description of the production of AR-SiS application (see Figure 1 and 2). The relevant content of the materials to be incorporated into the application based on Year 4 Science textbooks, specifically the introduction to the Solar System subtopic was also referred.

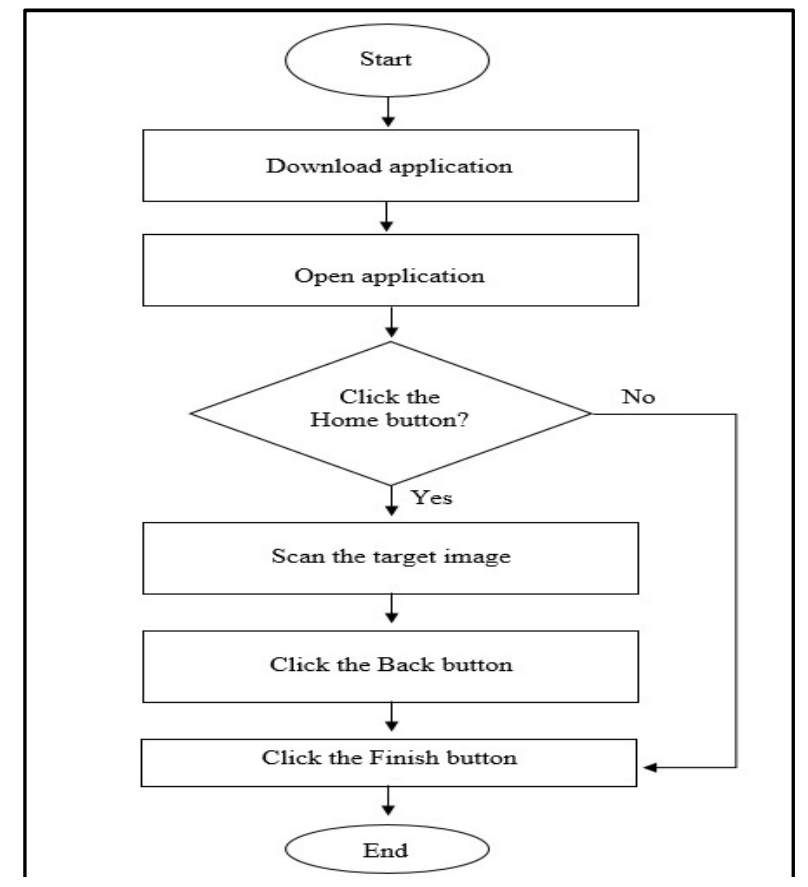

Figure 1. Application flow chart structure

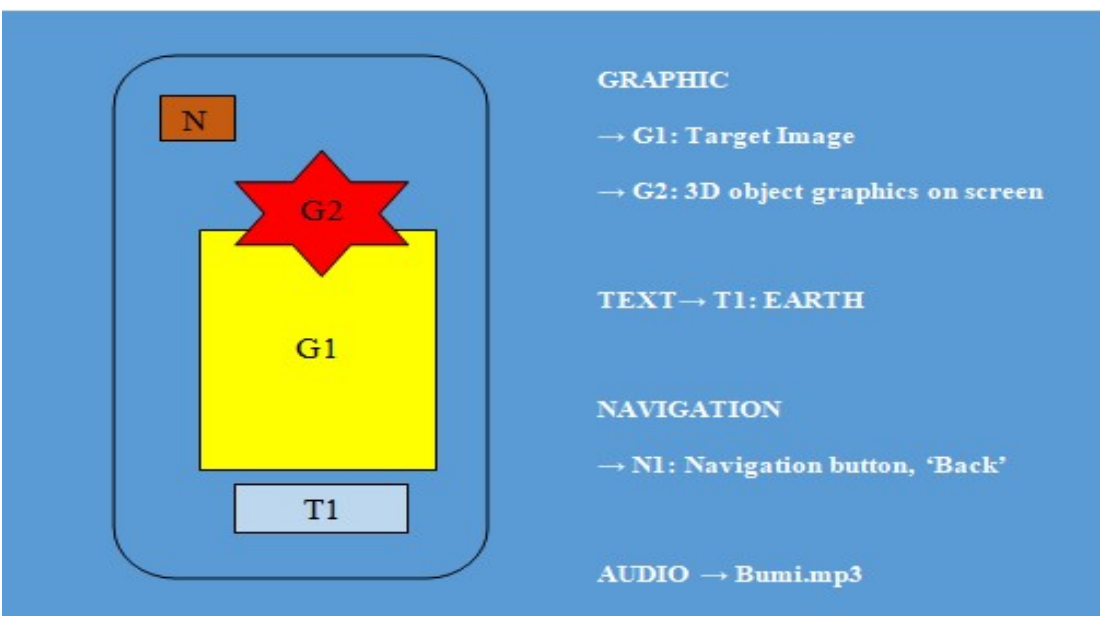

Figure 2. Example of image target display storyboard (Earth) 
The International Journal of Multimedia \& Its Applications (IJMA) Vol.10, No.6, December 2018

In the development phase, the AR-SiS application was developed based on the previous phase of the plan. Each graphic for the target image is generated and the audio is recorded and imported into the main authoring software, Unity 3D. The design of the AR-SiS application interface (as shown in Figures 3 and 4) is based on the direct manipulation concept which uses touch inputs or sensors that can receive user responses such as swiping, tapping, pinching and reverse pinching to manipulate objects on the phone or tablet touch screen. Therefore, the navigation button represents the user immediate response to input, which is designed to produce touch response to the application. In addition, explanation audio about the planet in the Malay language is also available and will be heard when the target image is scanned using a smartphone. The AR-SiS application is developed using $\mathrm{C} \#$ programming language and software such as Unity 3D, Vuforia, Blender, Adobe Photoshop CS6, Android Studio version 2.3 and Sound Recorder.

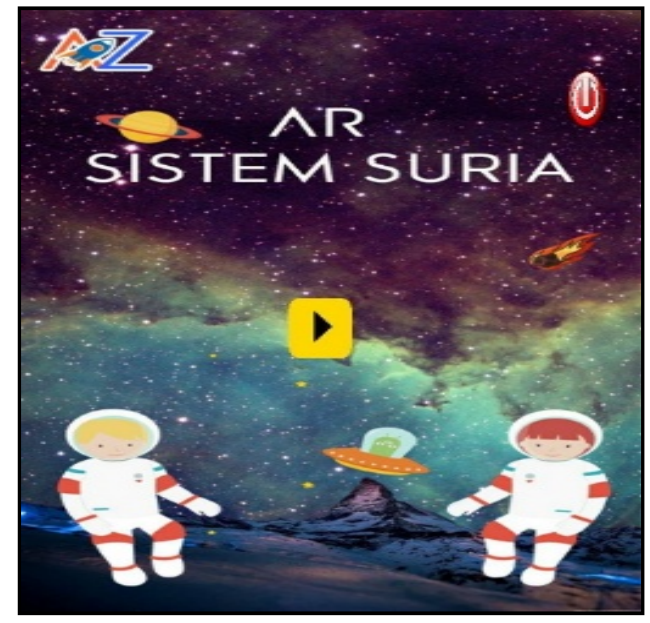

Figure 3. AR-SiS menu screen

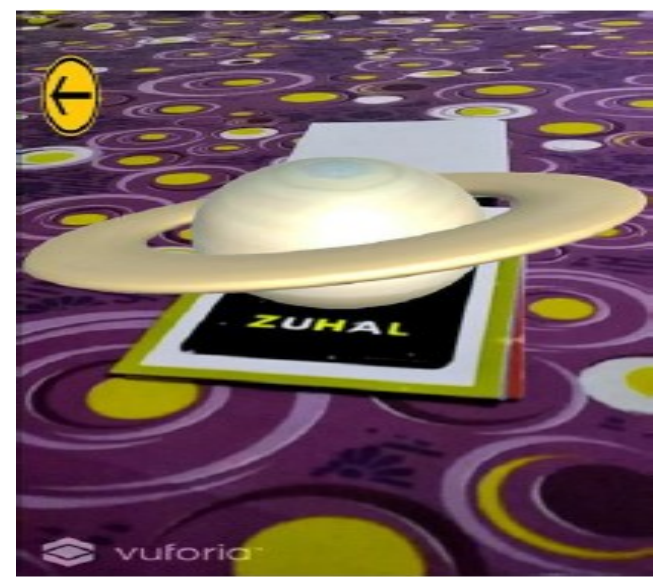

Figure 4. Examples of AR-SiS object screen

After the AR-SiS application is developed, this application is installed on a smartphone that uses the Android platform. Next, in the evaluation phase, two categories of respondents involved, teachers of Science subjects and Year 4 to Year 6 students that randomly selected at one of the primary schools in Pahang. There are two sets of questionnaires used to assess the usability of 
The International Journal of Multimedia \& Its Applications (IJMA) Vol.10, No.6, December 2018 AR-SiS application for learnability and satisfaction of teachers and students. Learnability refer to the extent to which something can be learned efficiency and satisfaction refers to the users' comfort and positive attitudes towards the use of the system [29].The set of questionnaires for teachers consists of 12 items and uses the Likert scale of five answer options, while the questionnaires for students consist of 10 items and uses a three-choice scale only to facilitate them to choose answers such as in Table 1 and Figure 5. Construction of the relevant items for the questionnaires for teachers and students were adapted from [30] and [31].

The assessment session was conducted by asking teachers and students to use the AR-SiS application and then to answer the questionnaires provided. Data from the questionnaires was analysed using the Microsoft Office Excel 2013 software program to facilitate the researcher to do comparisons and conclusions on AR-SiS application development. The researcher uses descriptive analysis method which is interpreted to several levels of tendency which are low, medium and high level [32]. The mean score obtained through descriptive statistics is interpreted to some degree of inclination as shown in Tables 2 and 3.

Table 1. Description of Likert scale (Teachers respondent)

\begin{tabular}{|c|c|}
\hline Scale & Definition \\
\hline 1 & Strongly disagree \\
\hline 2 & Agree \\
\hline 3 & Neither \\
\hline 4 & Disagree \\
\hline 5 & Strongly disagree \\
\hline
\end{tabular}

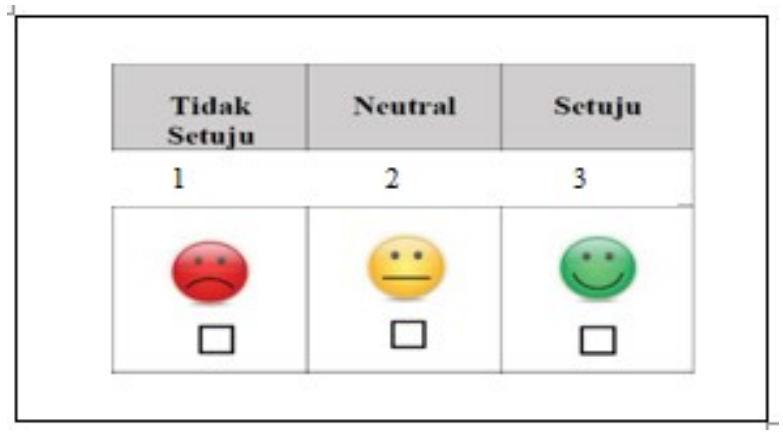

Figure 5. Description of Likert scale (Students respondent)

Table 2. Interpretation of mean score (Teachers Respondent)

\begin{tabular}{|c|c|}
\hline Level & Range \\
\hline Low & $1.00-2.33$ \\
\hline Medium & $2.34-3.67$ \\
\hline High & $3.68-5.00$ \\
\hline
\end{tabular}

Table 3. Interpretation of mean score modified by researcher (Students Respondent)

\begin{tabular}{|c|c|}
\hline Level & Range \\
\hline Low & $0.10-1.00$ \\
\hline Medium & $1.10-2.00$ \\
\hline High & $2.10-3.00$ \\
\hline
\end{tabular}


The International Journal of Multimedia \& Its Applications (IJMA) Vol.10, No.6, December 2018

\section{Data Analysis ANd Discussions}

\subsection{RESPONDENT BACKGROUND ANALYSIS}

According to [29], the number of samples for quantitative studies on usability assessments is at least 20 people. Thus, the researcher h selected five teachers who were all female teachers and 20 students aged from 10 to 12 years old comprising of 11 male students and 9 female students to be involved in the AR-SiS application usability assessment.

Table 4. Category and gender of respondent

\begin{tabular}{|c|c|c|c|}
\hline Respondent & Male & Female & Total \\
\hline Teachers & $0(0 \%)$ & $5(100 \%)$ & 5 \\
\hline Students & $11(55 \%)$ & $9(45 \%)$ & 20 \\
\hline \multicolumn{3}{|c|}{ Total } & $\mathbf{2 5}$ \\
\hline
\end{tabular}

\subsection{AR-SiS APPLICATION USABILITY ANALYSIS}

The findings from the respondents, which are teachers and students in terms of learnability and satisfaction regarding AR-SiS application are provided in Table 5 and 6 . The mean score average in Figure 6 shows that in the case of learnability, the two categories of respondents show high mean score average, namely 4.4 for teachers and 2.8 for students. This shows that both of respondent categories, whether the teacher or student can control the AR-SiS application well and easily even though it was their first time using during the assessment. They can also understand the use of the AR-SiS application well and believe that the use of this application can help improve knowledge of the solar system. Meanwhile, for satisfaction aspect, the mean score average in Figure 6 also shows a high value of 4.2 for teachers and 2.7 for students. This high mean value indicates that both the respondent categories are satisfied while using this AR-SiS application. This satisfaction can be illustrated when the AR-SiS application can be clearly seen and heard, as well as the colours, texts, images, pictures and background elements are interesting. It worth noting that AR-SiS application was used differently in solar system sub-topic and provided factual knowledge or helped students to become immersed in the educational context by superimposing digital elements related to the narrative of the lesson and also helped students to visualize 3D concrete or to increase students' visual perception [15]. In addition, by using audio in AR-SiS application for instance, can achieve a higher immersion in the learning context [9].

Table 5. Data finding from teacher respondent

\begin{tabular}{|c|c|c|c|}
\hline Aspect & Item & $\begin{array}{l}\text { Mean } \\
\text { Score }\end{array}$ & $\begin{array}{c}\text { Mean } \\
\text { Score } \\
\text { Average }\end{array}$ \\
\hline \multirow[t]{6}{*}{ Learnability } & This AR-SiS application is easy to control and use. & 5.00 & \multirow{6}{*}{4.40} \\
\hline & $\begin{array}{l}\text { This AR-SiS application is suitable to use as teaching aids } \\
\text { in the classroom. }\end{array}$ & 4.60 & \\
\hline & The content provided is easy to understand by students. & 4.20 & \\
\hline & $\begin{array}{l}\text { The AR-SiS app can help students to increase their } \\
\text { existing knowledge. }\end{array}$ & 4.00 & \\
\hline & $\begin{array}{l}\text { The use of image scan cards in this AR-SiS application is } \\
\text { easy to use. }\end{array}$ & 4.80 & \\
\hline & $\begin{array}{l}\text { Users are easy to understand the concept of solar systems } \\
\text { using this AR-SiS application. }\end{array}$ & 3.80 & \\
\hline
\end{tabular}


The International Journal of Multimedia \& Its Applications (IJMA) Vol.10, No.6, December 2018

\begin{tabular}{|l|l|c|}
\hline Satisfaction & The background used is very interesting. & 4.20 \\
\cline { 2 - 3 } & Audio in this AR-SiS application can be heard clearly. & 4.00 \\
\cline { 2 - 3 } & $\begin{array}{l}\text { 3D objects display in AR-SiS application can be seen } \\
\text { clearly. }\end{array}$ & 3.80 \\
\cline { 2 - 3 } & $\begin{array}{l}\text { This AR-SiS application interface meets the concept of } \\
\text { solar system. }\end{array}$ & 4.20 \\
\cline { 2 - 3 } & $\begin{array}{l}\text { Text elements in the AR-SiS application and the scan card } \\
\text { are interesting. }\end{array}$ & 4.80 \\
\cline { 2 - 3 } & $\begin{array}{l}\text { The graphical elements in this AR-SiS application is } \\
\text { appealing. }\end{array}$ & 400 \\
\hline
\end{tabular}

Table 6. Data finding from student respondent

\begin{tabular}{|c|c|c|c|}
\hline Aspect & Item & $\begin{array}{l}\text { Mean } \\
\text { Score }\end{array}$ & $\begin{array}{c}\text { Mean } \\
\text { Score } \\
\text { Average }\end{array}$ \\
\hline \multirow[t]{5}{*}{ Learnability } & I can use this AR-SiS application properly. & 3.00 & \multirow{5}{*}{2.80} \\
\hline & I can use this AR-SiS application easily. & 2.65 & \\
\hline & $\begin{array}{l}\text { I can understand the information delivered from this AR- } \\
\text { SiS application. }\end{array}$ & 2.80 & \\
\hline & $\begin{array}{l}\text { I can improve knowledge about Solar System through } \\
\text { this AR-SiS application. }\end{array}$ & 2.60 & \\
\hline & $\begin{array}{l}\text { I can understand the language used in this AR-SiS } \\
\text { application. }\end{array}$ & 2.95 & \\
\hline \multirow[t]{5}{*}{ Satisfaction } & I like the colors used in this AR-SiS application. & 2.70 & \multirow{5}{*}{2.70} \\
\hline & I like the images used in this AR-SiS application. & 2.45 & \\
\hline & $\begin{array}{l}\text { I find audio in this AR-SiS application can be heard } \\
\text { clearly. }\end{array}$ & 3.00 & \\
\hline & I like 3D-shaped planetary objects. & 2.60 & \\
\hline & I am satisfied with this AR-SiS application. & 2.75 & \\
\hline
\end{tabular}
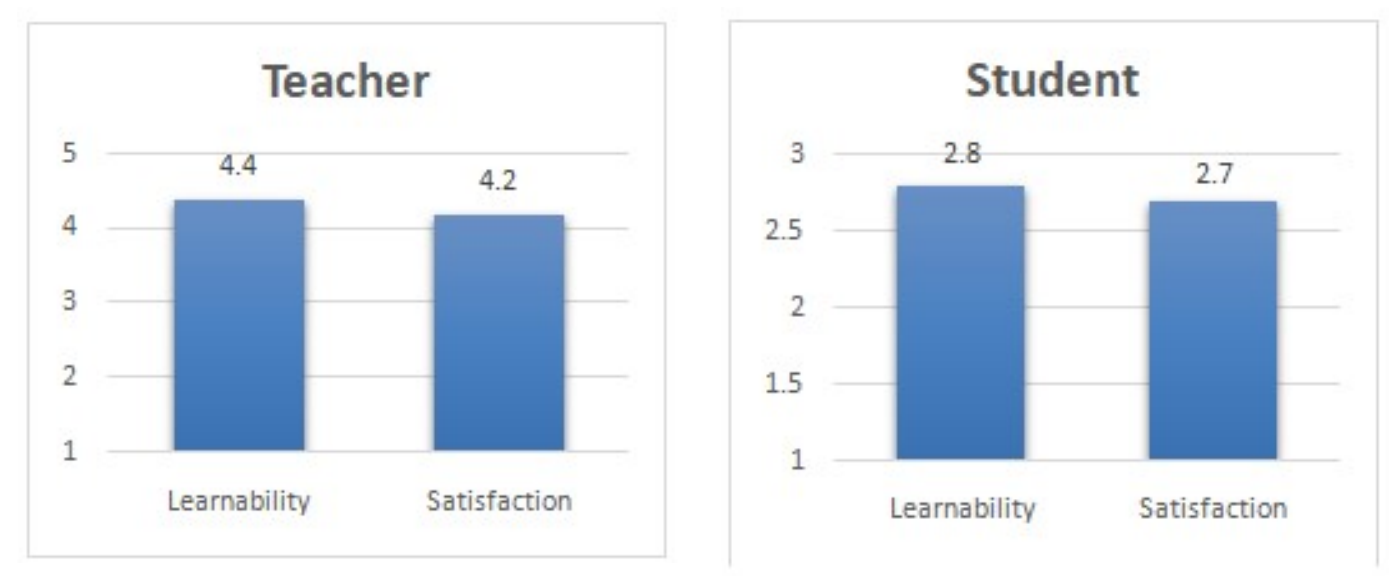

Note. Mean Score Average (Teacher) based on a scale of 1-5 while Mean Score Average (Student) on a scale of 1-3

Figure 6. Mean score average for teacher and student respondents 
The International Journal of Multimedia \& Its Applications (IJMA) Vol.10, No.6, December 2018

\section{CONCLUSION}

Science and mathematical concepts, when integrated into the Technology and Engineering field can be used as a platform for solving real-world problems in life as well as providing a very effective learning experience for students. The findings of this study showed that AR-SiS application is easy to use and the application can be learnt and understood by users. Thus, encourages respondents to be satisfied with the developed AR-SiS application. However, there are some suggestions for improvements to produce better and effective AR-SiS application. First, the design of each target image were almost similar to each other that causes a confusion in the scan of the target images, thus, the 3D object appears unlike the scanned target image. Therefore, the target image should be designed properly to avoid causing confusion while the user scans it in terms of colours, graphics and text layout on the image to be generated. Next, the navigation button on the smart phone screen is small for users who use small-sized smartphones. Hence, the navigation buttons should be designed to suit all sizes of smartphones. In a nutshell, the production of AR-SiS application is beneficial not only to attract students to study Science subjects, especially astronomy, but it can help teachers in delivering the lesson content with the help of more interesting teaching techniques, as well as aids and fulfils the perception of the current generation. In addition, it is a good idea to both parties where teachers can improve their teaching methods and students can learn new knowledge in accordance with the applied technology.

\section{REFERENCES}

[1] Bacca, J., Baldiris, S., Fabregat, R., Graf, S., \& Kinshuk. (2014). Augmented Reality Trends in Education: A Systematic Review of Research and Applications. Educational Technology \& Society, 17(4), 133-149. https://doi.org/ISSN 1436-4522 (online)

[2] Chen, C.-M., \& Tsai, Y.-N. (2012). Interactive Augmented Reality Game for Enhancing Library Instruction in Elementary Schools. Computers \& Education, 59, 638-652.

[3] Sungkur, R. K., Panchoo, A., \& Bhoyroo, N. K. (2016). Augmented reality, the future of contextual mobile learning. Interactive Technology and Smart Education, 13(2), 123-146. https://doi.org/10.1108/ITSE-07-2015-0017

[4] Lin, C.-Y., Chai, H.-C., Wang, J., Chen, C.-J., Liu, Y.-H., Chen, C.-W., Huang, Y.-M. (2016). Augmented reality in educational activities for children with disabilities. Displays, 42, 51-54. https://doi.org/https://doi.org/10.1016/j.displa.2015.02.004

[5] Johnson, L., Adams, B., Estrada, V., \& Freeman, A. (2014). Horizon Report: 2014 K-12 Edition. Horizon Report. https://doi.org/ISBN 978-0-9914828-5-6

[6] Muhammad Abd Hadi Bunyamin. (2015, November). Pendidikan STEM Bersepadu: Perspektif Global, Perkembangan Semasa di Malaysia, dan Langkah Kehadapan. Buletin Persatuan Pendidikan Sains Dan Matematik Johor, (25(1)), 1-6. Retrieved from https://www.researchgate.net/publication/301567750

[7] Hazlina Aziz. (2018, March 14). Making STEM a priority for students. Retrieved from https://www.nst.com.my/opinion/columnists/2018/03/344956/making-stem-priority-students

[8] Taucan, R. J. (2017, October 30). Hanya 21 peratus pelajar minat STEM. Retrieved from http://www.utusan.com.my/berita/nasional/hanya-21-peratus-pelajar-minat-stem-1.544994

[9] Ibáñez, M. B., \& Delgado-Kloos, C. (2018). Augmented reality for STEM learning: A systematic review. Computers and Education, 123, 109-123. https://doi.org/10.1016/j.compedu.2018.05.002

[10] Hsu, Y.-S., Lin, Y.-H., \& Yang, B. (2017). Impact of augmented reality lessons on students' STEM interest. Research and Practice in Technology Enhanced Learning, 12(1), 2. https://doi.org/10.1186/s41039-016-0039-z 
The International Journal of Multimedia \& Its Applications (IJMA) Vol.10, No.6, December 2018

[11] Restivo, T., Chouzal, F., Rodrigues, J., Menezes, P., \& Lopes, J. B. (2014). Augmented reality to improve STEM motivation. IEEE Global Engineering Education Conference, EDUCON, (April 2014), 803-806. https://doi.org/10.1109/EDUCON.2014.6826187

[12] Gebril, Z. M., Ah-choo, K., May-chan, Y., \& Parhizkar, B. (2012). Innovative Learning of Solar System using Augmented Reality for Primary School Children. International Proceedings of Economics Development \& Research, 41(June), 156-160.

[13] Chen, C.-M., \& Tsai, Y.-N. (2012). Interactive Augmented Reality Game for Enhancing Library Instruction in Elementary Schools. Computers \& Education, 59, 638-652.

[14] Freeman, B., Marginson, S., \& Tytler, R. (2014). The Age of STEM: Educational Policy and Practice Across the World in Science, Technology, Engineering and Mathematics. Routledge.

[15] Cuendet, S., Bonnard, Q., Do-Lenh, S., \& Dillenbourg, P. (2013). Designing augmented reality for the classroom. Computers \& Education, 68, 557-569. https://doi.org/https://doi.org/10.1016/j.compedu.2013.02.015

[16] Wojciechowski, R., \& Cellary, W. (2013). Evaluation of learners' attitude toward learning in ARIES augmented reality environments. Computers \& Education, 68, 570-585. https://doi.org/https://doi.org/10.1016/j.compedu.2013.02.014

[17] Chen, P., Liu, X., Cheng, W., \& Huang, R. (2017). A review of using Augmented Reality in Education from 2011 to 2016. In Innovations in Smart Learning. https://doi.org/10.1007/978-981-102419-1_2

[18] Ramírez, P., Ramírez, H., Infante, L. D., López, J. M., Rosquillas, J., Villegas, A. L., ... de la Vega, D. (2013). Explora México: A Mobile Application to Learn Mexico's Geography. Procedia Computer Science, 25, 194-200. https://doi.org/https://doi.org/10.1016/j.procs.2013.11.024

[19] Chen, M. P., \& Liao, B. C. (2015). Augmented reality laboratory for high school electrochemistry course. In Proceedings - IEEE 15th International Conference on Advanced Learning Technologies: Advanced Technologies for Supporting Open Access to Formal and Informal Learning, ICALT 2015. https://doi.org/10.1109/ICALT.2015.105

[20] Dinis, F. M., Guimaraes, A. S., Carvalho, B. R., \& Martins, J. P. P. (2017). Virtual and augmented reality game-based applications to civil engineering education. In 2017 IEEE Global Engineering Education Conference (EDUCON). https://doi.org/10.1109/EDUCON.2017.7943075

[21] Godwin-Jones, R. (2016). Emerging Technologies Augmented Reality and Language Learning : From Annotated Vocabulary To Place-Based Mobile Games. Language Learning \& Technology. https://doi.org/10.1145/1508044.1508049

[22] Zulham Adami, F., \& Budihartanti, C. (2016). Penerapan Teknologi Augmented Reality pada Media Pembelajaran Sistem Pencernaan Berbasis Android. Teknik Komputer AMIK BSI, II(1).

[23] Kraut, B., \& Jeknić, J. (2015). Improving education experience with augmented reality (AR). In 2015 38th International Convention on Information and Communication Technology, Electronics and Microelectronics, MIPRO 2015 - Proceedings. https://doi.org/10.1109/MIPRO.2015.7160372

[24] Lee, H.-C., Huang, C.-L., Ho, S.-H., \& Sung, W.-H. (2017). The Effect of a Virtual Reality Game Intervention on Balance for Patients with Stroke: A Randomized Controlled Trial. Games for Health Journal, 6(5), g4h.2016.0109. https://doi.org/10.1089/g4h.2016.0109

[25] NGSS Lead States. (2013). Next Generation Science Standards: For States, By States. Washington, DC: The National Academies Press. https://doi.org/10.17226/18290

[26] Mazlini Adnan, Aminah Ayob, Ong Eng Tek, Mohd Nasir Ibrahim, Noriah Ishak, \& Jameyah Sheriff. (2016). Memperkasa pembangunan modal insan Malaysia di peringkat kanak- kanak: Kajian kebolehlaksanaan dan kebolehintegrasian pendidikan STEM dalam kurikulum PERMATA Negara. GEOGRAFIA Online Malaysian Journal of Society and Space, 12(1), 29-36. Retrieved from http://journalarticle.ukm.my/9799/

[27] Wang, X. (2013). Why Students Choose STEM Majors: Motivation, High School Learning, and Postsecondary Context of Support. American Educational Research Journal, 50(5), 1081-1121. https://doi.org/10.3102/0002831213488622

[28] Pantelić, A., \& Vukovac, D. P. (2017). The Development of Educational Augmented Reality Application: A Practical Approach. In 10th International Conference of Education, Research and Innovation (pp. 8745-8752). 
The International Journal of Multimedia \& Its Applications (IJMA) Vol.10, No.6, December 2018

[29] Nielsen, J. (1993). Usability engineering. Morgan Kaufmann. California. https://doi.org/10.1145/1508044.1508050

[30] Marina Ismail, Norizan Mat Diah, Suzana Ahmad, Nor Ashikin Mohamad Kamal, \& Mohd Khairulnizam Md Dahari. (2011). Measuring Usability of Educational Computer Games Based on The User Success Rate. SHUSER 2011 - 2011 International Symposium on Humanities, Science and Engineering Research, 56-60. https://doi.org/10.1109/SHUSER.2011.6008500

[31] Grossman, T., Fitzmaurice, G., \& Attar, R. (2009). A Survey of Software Learnability: Metrics, Methodologies and Guidelines. CHI '2009, 649-658.

[32] Landell, K. (1997). Management by Menu. London: Wiley and Sons Inc.

\section{Authors}

Nadia Akma binti Ahmad Zaki is a Lecturer at Faculty of Art, Computing and Creative Industry. She received her first degree in Information Technology from Universiti Kebangsaan Malaysia and a Master's of Science (Computer Science) from Universiti Teknologi MARA. Her research interests are serious games, humancomputer interaction, and multimedia application development.

Nor Zuhaidah Mohamed Zainis a lecturer in Department of Computing, Faculty of Arts, Computing and Creative Industry at Universiti Pendidikan Sultan Idris since January 2016. Previously, she served to Department of Multimedia Creative at the same faculty and university since June 2005. She is currently in the process of completing her Ph.D. at International Islamic University Malaysia (IIUM) in humancomputer interaction (HCI) research field. Her research interests lie in the area of multimedia learning in education and implementation of mobile learning, focusing on special education needs.

Asmafitri Zanilabdin is a graduate in Bachelor of Education (Multimedia) Hons and currently a Master of Education (Instructional Technology) student. Her research interests are education, augmented reality and virtual reality.
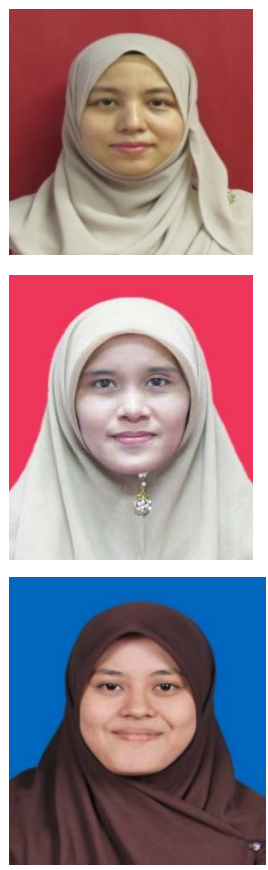